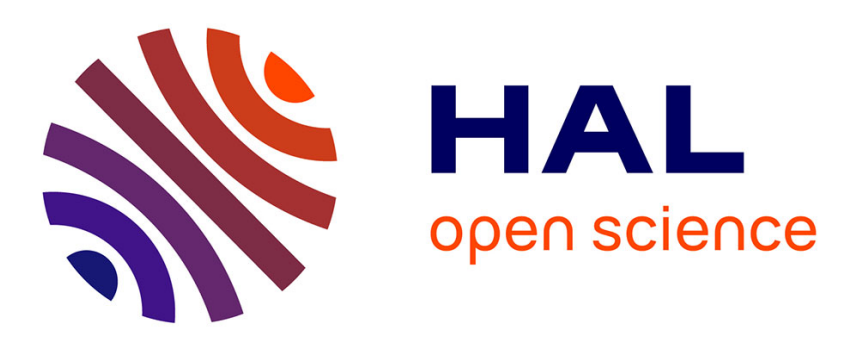

\title{
Use of MCDM techniques in environmentally conscious manufacturing and product recovery: State of the art
}

Mehmet Ali Ilgin, Surendra M. Gupta, Olga Battaïa

\section{To cite this version:}

Mehmet Ali Ilgin, Surendra M. Gupta, Olga Battaïa. Use of MCDM techniques in environmentally conscious manufacturing and product recovery: State of the art. Journal of Manufacturing Systems, 2015, 37, pp.Pages 746-758. 10.1016/j.jmsy.2015.04.010 • emse-01145818

\section{HAL Id: emse-01145818 \\ https://hal-emse.ccsd.cnrs.fr/emse-01145818}

Submitted on 21 Aug 2018

HAL is a multi-disciplinary open access archive for the deposit and dissemination of scientific research documents, whether they are published or not. The documents may come from teaching and research institutions in France or abroad, or from public or private research centers.
L'archive ouverte pluridisciplinaire HAL, est destinée au dépôt et à la diffusion de documents scientifiques de niveau recherche, publiés ou non, émanant des établissements d'enseignement et de recherche français ou étrangers, des laboratoires publics ou privés. 


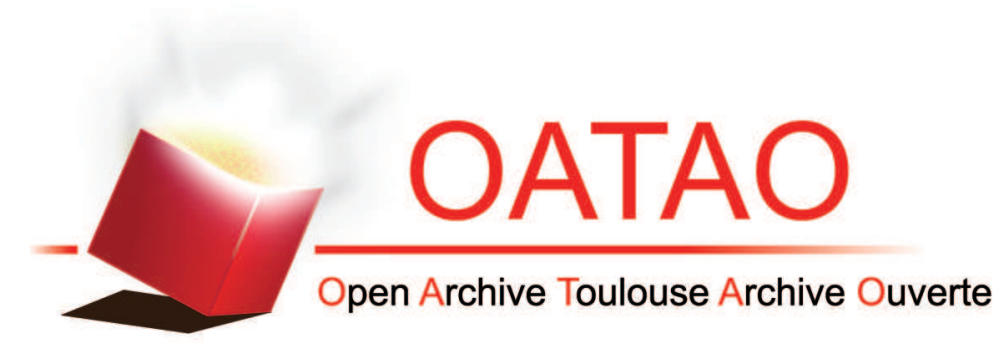

\section{Open Archive Toulouse Archive Ouverte (OATAO)}

OATAO is an open access repository that collects the work of some Toulouse researchers and makes it freely available over the web where possible.

This is an author's version published in: https://oatao.univ-toulouse.fr/20102

Official URL : http://dx.doi.org/10.1016/j.jmsy.2015.04.0101

\section{To cite this version :}

Ilgin, Mehmet Ali and Gupta, Surendra M. and Battaïa, Olga Use of MCDM techniques in environmentally conscious manufacturing and product recovery: State of the art. (2015) Journal of Manufacturing Systems, 37. 746-758. ISSN 0278-6125

Any correspondence concerning this service should be sent to the repository administrator: tech-oatao@listes-diff.inp-toulouse.fr 


\title{
Use of MCDM techniques in environmentally conscious manufacturing and product recovery: State of the art
}

\author{
Mehmet Ali Ilgin $^{\mathrm{a}, *}$, Surendra M. Gupta ${ }^{\mathrm{b}, 1}$, Olga Battaïa ${ }^{\mathrm{c}}$ \\ a Department of Industrial Engineering, Celal Bayar University, Muradiye Campus, 45140 Manisa, Turkey \\ ${ }^{\mathrm{b}}$ Laboratory of Responsible Manufacturing, 334 SN Department of MIE, Northeastern University, Boston, MA 02115, USA \\ c École Nationale Supérieure des Mines, CNRS UMR6158 LIMOS, F-42023 Saint-Étienne, France
}

Keywords:

Environmentally conscious manufacturing Product recovery

Multi criteria decision making

Review

\begin{abstract}
A B S T R A C T
Increasing environmental awareness of customers and stricter environmental regulations by local governments force manufacturers to invest in environmentally conscious manufacturing which involves the application of green principles to all phases of a product's life cycle from conceptual design to final delivery to consumers, and ultimately to the end of life (EOL) disposal. They also setup facilities for product recovery which is the recovery of materials and components from returned or EOL products via disassembly, recycling and remanufacturing. To address these new issues efficiently, multi criteria decision making (MCDM) techniques are used in order to evaluate the economic and environmental indicators. This paper presents over 190 MCDM studies in environmentally conscious manufacturing and product recovery (ECMPRO) by classifying them into three major categories. Insights from the review and future research directions conclude the paper.
\end{abstract}

\section{Introduction}

Substantial improvements in the efficiency of the resource use in manufacturing and reduction of the wastes and emissions generated are required in order to not compromise the health and life standards of future generations. As a response to this societal challenge, stricter environmental regulations and new customer requirements oblige firms to invest in environmentally conscious manufacturing which involves the evaluation of environmental performances of all phases in a product's life cycle (i.e., from material selection to end of life processing option). Due to its social, environmental and economic benefits, product recovery through reverse supply chains is also gaining more and more industrial interest $[1,2]$. Product recovery preserves resources by reducing the consumption of verging raw materials, water and energy. In addition, this process plays a key role in minimizing the amount of waste sent to landfills and diminishing air and water pollution $[3,4]$. Through recycling, remanufacturing and reuse, product recovery aims to retrieve valuable parts and materials from discarded or end of life (EOL) products.

\footnotetext{
* Corresponding author. Tel.: +90 2362012210.

E-mail addresses: mehmetali.ilgin@cbu.edu.tr (M.A. Ilgin), gupta@Neu.Edu (S.M. Gupta), battaia@emse.fr (O. Battaïa).

1 Tel.: +1 6173734846 .
}

It had come naturally to firms to evaluate the economic and environmental benefits of such initiatives. Since different kinds of indicators have to be compared in this case, the multi criteria decision making (MCDM) techniques appeared to be the appropriate tools to use. This review presents an analysis of the application of different MCDM techniques in order to help the decision makers implement environmentally conscious manufacturing principles or to engage them in product recovery activities. Over 190 scientific articles published between 1996 and 2014 are concerned by this study.

Fig. 1 presents a global view of a closed-loop supply chain (CLSC). The analysis of the academic literature showed that the topics most addressed with MCDM are green supplier selection and evaluation, disassembly planning, reverse logistics and CLSC design, etc. This is highlighted in Fig. 1 and detailed in Fig. 2 and Table 1.

It was shown in several studies that disassembly is a critical operation in product recovery process since all product disposal options (e.g., recycling, remanufacturing) require the disassembly of EOL products at some level [198-200]. Significant improvements can be achieved in the profitability of product recovery options by effectively planning disassembly process. One of the important disassembly planning problems is the disassembly to order problem which involves the determination of the number of EOL products to process to fulfill a certain demand for products, parts and/or materials under a variety of objectives and constraints.

The MCDM techniques are used both for evaluation and design problems, the major distinction between them is based on whether 


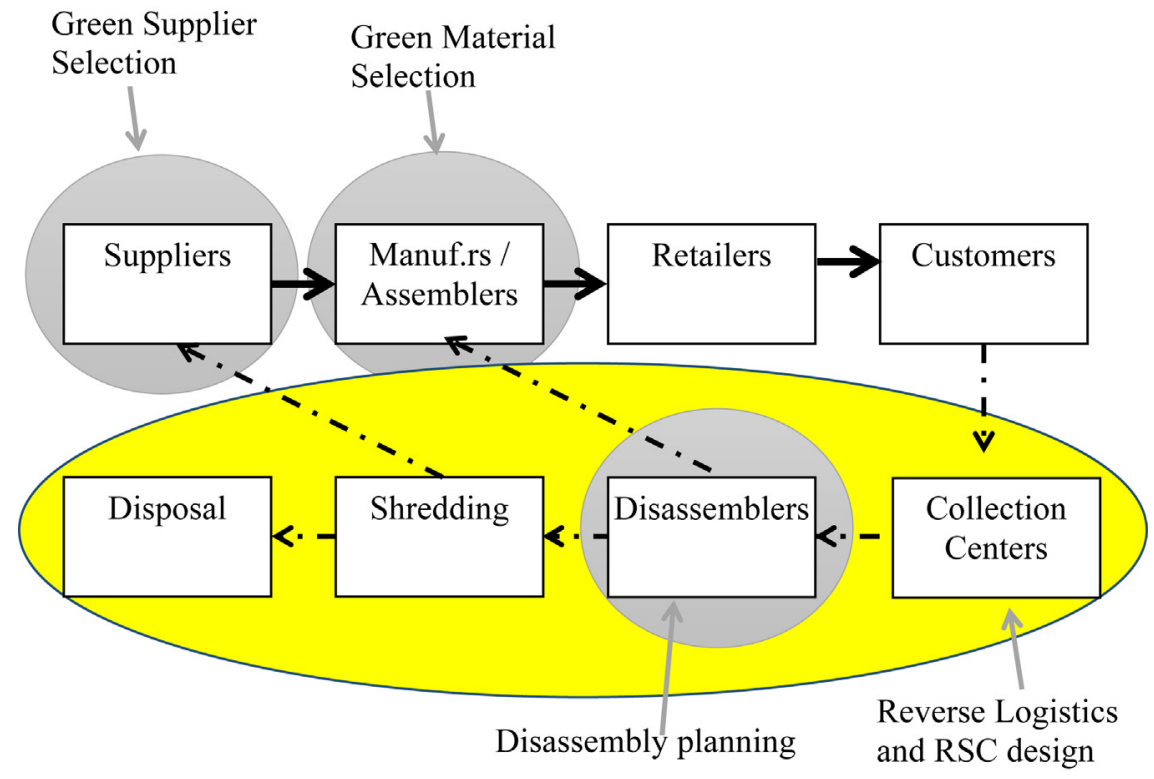

Fig. 1. Closed-loop supply chain.

the solutions/alternatives are explicitly (evaluation problems) or implicitly (design problems) defined. Another criterion of the classification of MCDM techniques is the intervention of the decision maker which can be required a priori (given goals, weights for the objectives), interactive or a posteriori (sorting of given solutions). Based on these observations, the rest of the article is organized in the following way. First, the techniques that are used for searching for new solutions under consideration of multiple optimization objectives are presented in Section 2. This category includes such well known techniques as goal programming and physical programming but also the heuristics and metaheuristics. Section 3 overviews the techniques used for the classification of feasible solutions and Pareto-based ranking. Section 4 overviews the studies implementing both optimization and classification techniques. Finally, concluding remarks are given in Section 5.

\section{Multi-objective optimization techniques}

These techniques aim at achieving the optimal or aspired goals by considering the various interactions within the given constraints [201].

\subsection{Multi-objective linear and non-linear programming}

Wang et al. [64] develop a multi-objective mixed-integer programming formulation for a green supply chain network design problem by considering the trade-off between the total cost and the environment influence. They apply the normalized normal constraint method to solve the multi-objective model. Pishvaee and Razmi [70] design an environmental supply chain under uncertainty using multi-objective fuzzy mathematical programming. There are two objectives (viz., minimizing the total cost and minimizing the total environmental impact) and the multiobjective programming model is solved by using $\varepsilon$-constraint method. Ramezani et al. [72] present a stochastic multiobjective model for the design of a forward/reverse supply chain network with the goals of maximization of profit, maximization of responsiveness and minimization of defective parts from suppliers. $\varepsilon$-Constraint method is used to determine a set of Pareto-optimal supply chain configuration. Özkır and Başlıgil [73] propose a fuzzy multi-objective optimization model for the design of a closed-loop supply chain network by considering three objectives: maximizing satisfaction level of trade, maximizing satisfaction degrees of
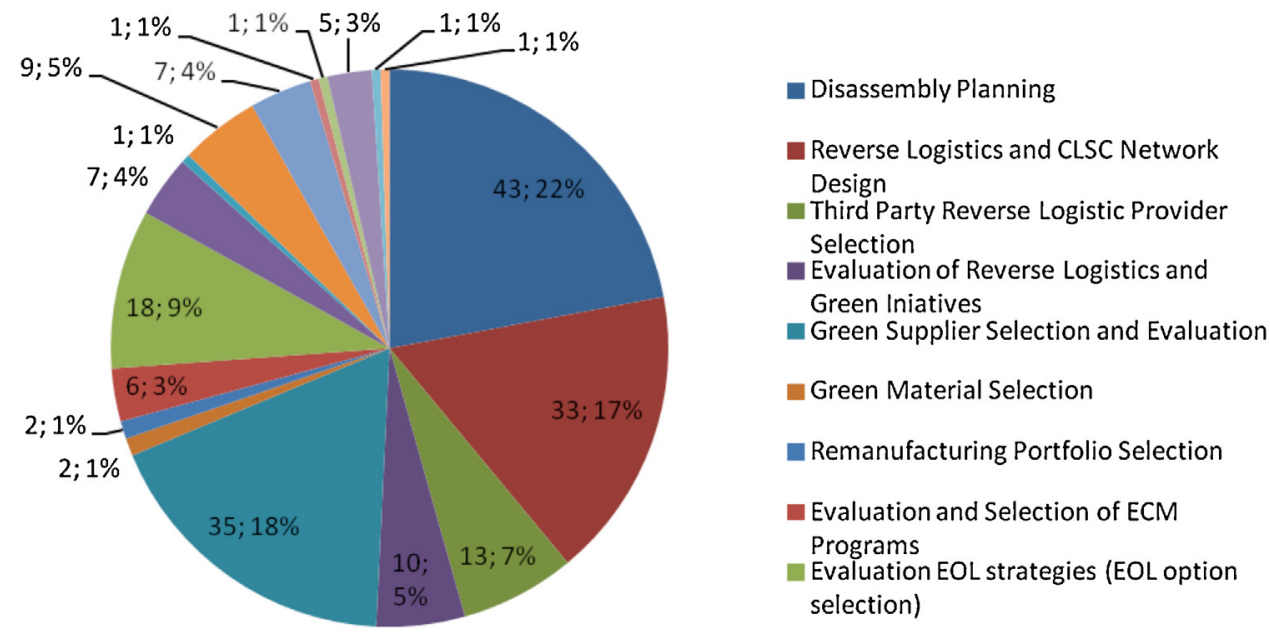

Fig. 2. Main decision and optimization problems addressed in ECMPRO. 
Table 1

Classification of references based on ECMPRO issues.

\begin{tabular}{|c|c|}
\hline Issue & References \\
\hline Disassembly planning & $\begin{array}{l}\text { Gupta and Taleb [5]; Taleb and Gupta [6]; Zeid et al. [7]; Kongar and Gupta [8]; Gupta and Veerakamolmal [9]; } \\
\text { Veerakamolmal and Gupta [10]; Kongar et al. [11]; Lambert and Gupta [12]; Imtanavanich and Gupta [13-17]; } \\
\text { McGovern and Gupta [18]; Langella [19]; McGovern and Gupta [20]; Agrawal and Tiwari [21]; McGovern and } \\
\text { Gupta [22]; Lu et al. [23]; Kongar and Gupta [24]; Xanthopoulos and Iakovou [25]; Ding et al. [26,27]; Massoud } \\
\text { and Gupta [28,29]; Kongar and Gupta [30]; Ondemir and Gupta [31]; Guo et al. [32]; Wang et al. [33]; Avikal } \\
\text { et al. [34,35]; Rickli and Camelio [36]; Aydemir-Karadag and Turkbey [37]; Avikal et al. [38]; Ghazilla et al. } \\
\text { [39]; Kalayci and Gupta [40-45]; Ondemir and Gupta [46,47]. }\end{array}$ \\
\hline Reverse logistics and CLSC network design & $\begin{array}{l}\text { Pochampally et al. [48]; Pochampally and Gupta [49]; Gupta and Nukala [50]; Nukala and Gupta [51,52]; } \\
\text { Pochampally and Gupta [53]; Pochampally et al. [54]; Tuzkaya and Gulsun [55]; Dehghanian and Mansour } \\
\text { [56]; Pochampally et al. [57,58]; Barker and Zabinsky [59]; Buyukozkan and Berkol [60]; Harraz and Galal } \\
\text { [61]; Chaabane et al. [62]; Sasikumar and Haq [63]; Wang et al. [64]; Paksoy et al. [65]; Jamshidi et al. [66]; } \\
\text { Ilgin and Gupta [67]; Pochampally and Gupta [68]; Mehrbod et al. [69]; Pishvaee and Razmi [70]; Samanlioglu } \\
\text { [71]; Ramezani et al. [72]; Özkır and Başlıgil [73]; Ozceylan and Paksoy [74,75]; Shokohyar and Mansour [76]; } \\
\text { Ghorbani et al. [77]; Mirakhorli [78]; Nurjanni et al. [79]; Wang et al. [80]. }\end{array}$ \\
\hline Third party reverse logistic provider selection & $\begin{array}{l}\text { Meade and Sarkis [81]; Efendigil et al. [82]; Kannan et al. [83]; Saen [84]; Cheng and Lee [85]; Saen [86,87]; } \\
\text { Azadi and Saen [88]; Zhou et al. [89]; Ravi [90]; Govindan et al. [91]; Zareinejad and Javanmard [92]; Senthil } \\
\text { et al. [93]. }\end{array}$ \\
\hline Evaluation of reverse logistics and green initiatives & $\begin{array}{l}\text { Ravi et al. [94]; Chiou et al. [95]; Sarmiento and Thomas [96]; Büyüközkan and Çiftçi [97]; Chiou et al. [98]; } \\
\text { Senthil et al. [99]; Shaverdi et al. [100]; Lin [101]; Wang and Chan [102]; Mangla et al. [103]. }\end{array}$ \\
\hline Green supplier selection and evaluation & $\begin{array}{l}\text { Noci [104]; Handfield et al. [105]; Humphreys et al. [106]; Zhang et al. [107]; Humphreys et al. [108]; Nukala } \\
\text { and Gupta [109]; Hsu and Hu [110]; Lu et al. [111]; Yang and Wu [112]; Yu-zhong and Li-yun [113]; Ge [114]; } \\
\text { Hsu and Hu [115]; Lee et al. [116]; Li and Zhao [117]; Tuzkaya et al. [118]; Chen et al. [119]; Awasthi et al. } \\
\text { [120]; Grisi et al. [121]; Kumar and Jain [122]; Feyzioglu and Büyüközkan [123]; Thongchattu and } \\
\text { Siripokapirom [124]; Wen and Chi [125]; Büyüközkan and Çiftçi [126]; Ciftci and Buyukozkan [127]; Shaik and } \\
\text { Abdul-Kader [128]; Datta et al. [129]; Dai and Blackhurst [130]; Amin and Zhang [131]; Lee et al. [132]; } \\
\text { Govindan et al. [91]; Kuo and Lin [133]; Punniyamoorty et al. [134]; Hsu et al. [135]; Kannan et al. [136]; Shen } \\
\text { et al. [137]. }\end{array}$ \\
\hline Green material selection & Kim et al. [138]; Sakundarini et al. [139]. \\
\hline Remanufacturing portfolio selection & Jiang et al. [140]; Subramoniam et al. [141] \\
\hline Evaluation and selection of ECM programs & Sarkis [142,143]; Rao [144]; Vinodh et al. [145]; Diabat et al. [146]; Ziout et al. [147]. \\
\hline Evaluation of EOL strategies (EOL option selection) & $\begin{array}{l}\text { Lee et al. [148]; Kongar et al. [11]; Hula et al. [149]; Bufardi et al. [150]; Ravi et al. [151]; Kongar and Gupta } \\
\text { [152]; Jun et al. [153]; Chan [154]; Chen et al. [155]; Wadhwa et al. [156]; Iakovou et al. [157]; Rao and } \\
\text { Padmanabhan [158]; Ghazalli and Murata [159]; Chen et al. [160]; Remery et al. [161]; Mahapatara et al. } \\
\text { [162]; Samantra et al. [163]; Dhouib [164]. }\end{array}$ \\
\hline Evaluation of recycling alternatives and programs & $\begin{array}{l}\text { Gupta and Isaacs [165]; Isaacs and Gupta [166]; Boon et al. [167]; Yu et al. [168]; Boon et al. [169]; Gupta and } \\
\text { Pochampally [170]; Yeh and Xu [171]. }\end{array}$ \\
\hline Operational issues in CLSC & Gupta and Evans [172]. \\
\hline Green design & $\begin{array}{l}\text { Azzone and Noci [173]; Gungor [174]; Kuo et al. [175]; Choi et al. [176]; Li et al. [177]; Gao et al. [178]; Kuo } \\
\text { [179]; Wang et al. [180]; Vinodh et al. [181]. }\end{array}$ \\
\hline Performance measurement of GSCs & $\begin{array}{l}\text { Erol et al. [182]; Hsu et al. [183]; De Felice and Petrillo [184]; Shaik and Abdul-Kader [185]; Bhattacharya et al. } \\
\text { [186]; Sangwan [187]; Mirhedayatian et al. [188]. }\end{array}$ \\
\hline Inventory problems & Bouchery et al. [189]. \\
\hline Evaluation of waste treatment strategies & Bereketli et al. [190]. \\
\hline Other & $\begin{array}{l}\text { Walther et al. [191]; Vadde et al. [192]; Wittstruck and Teuteberg [193]; Chern et al. [194]; Liu and Huang } \\
\text { [195]. }\end{array}$ \\
\hline Green supplier development & Dou et al. [196]. \\
\hline Partner selection & Yeh and Chuang [197]. \\
\hline
\end{tabular}

customers and maximizing total closed-loop supply chain profit. The mixed integer programming model proposed by Ozceylan and Paksoy [75] determines the optimum transportation amounts together with the location of plants and retailers by considering multiple periods and multiple parts. The proposed model is based on the minimization of transportation, purchasing, refurbishing and fixed costs and scenario analysis is used to investigate the effect of various parameters (demand, capacity etc.). Ozceylan and Paksoy [74] develop a fuzzy multi-objective linear programming model for the design of a closed-loop supply chain by considering the uncertainty associated with capacity, demand and reverse rates. There are two objectives of the model: minimization of total manufacturing and distribution costs and minimization of total fixed costs of plants and retailers. Mirakhorli [78] proposes an interactive fuzzy multi-objective linear programming model to solve a fuzzy bi-objective (viz., minimization of total cost and minimization of total delivery time) reverse logistics network design problem. Pareto optimal solutions are obtained using weighted sum approach. Nurjanni et al. [79] integrate three scalarization approaches, namely weighted sum method, weighted Tchebycheff and augmented weighted Tchebycheff to solve the mathematical model associated with a closed-loop supply chain network.
The model minimizes overall costs and carbon dioxide emissions. Samanlioglu [71] proposes a multi-objective mixed integer model for the location-routing decisions of industrial hazardous material management. Minimization of the total cost, minimization of the total transportation risk and minimization of the total risk for the population around treatment and disposal centers are the objectives of the model and the multi-objective programming model is solved by using lexicographic weighted Tchebycheff method.

Bouchery et al. [189] reformulate the classical economic order quantity model as a multiobjective problem and call it as sustainable order quantity model. They also considered a multi-echelon extension of this model. The set of efficient solutions (Pareto optimal solutions) is analytically characterized for both models. In addition, an interactive procedure helping decision makers in the quick identification of the best option among these solutions is proposed.

\subsection{Crisp and fuzzy goal programming}

Goal programming is an extension of linear programming due to its ability of handling multiple and often conflicting objectives 
[202]. Two variants of goal programming are prevalent in the literature. The first one is known as lexicographic or preemptive goal programming while the second one is termed weighted or non-preemptive goal programming. Preemptive goal programming assumes that all goals can be clearly prioritized and that satisfying a higher priority goal should carry more importance than a lower priority goal. Non-preemptive goal programming assumes that all goals should be pursued. However, in this case, all deviations from the goals are multiplied by some weights (based on their relative importance) and summed up to form a single utility function that is optimized.

Kongar and Gupta [8] present a preemptive integer goal programming model for the disassembly-to-order process so as to satisfy various economical, physical and environmental goals simultaneously. Imtanavanich and Gupta [14] use preemptive goal programming for solving the multi-criteria disassembly-to-order problem under stochastic yields. Massoud and Gupta [29] extend Imtanavanich and Gupta [14] by using preemptive goal programming to solve a similar problem under stochastic yields, limited supply, and quantity discount.

McGovern and Gupta [22] use lexicographic goal programming to solve disassembly line balancing problem which involves the determination of a sequence of parts for removal from an end of life product that minimizes the resources for disassembly and maximizes the automation of the process and the quality of the parts or materials recovered. In Xanthopoulos and Iakovou [25], lexicographic goal programming is employed to determine the most desirable components of an EOL product to be non-destructively disassembled. Ondemir and Gupta [47] develop a lexicographic mixed-integer goal programming model for an advanced remanufacturing-to-order and disassembly-toorder system utilizing the life-cycle data collected, stored and delivered by the Internet of Things.

Goal programming is employed in Gupta and Isaacs [165] to investigate the effect of lightweighting on the dismantler and shredder profitabilities associated with EOL vehicle recycling industry of USA. Isaacs and Gupta [166] propose a goal programming based methodology to explore changes to the current U.S. vehicle recycling infrastructure considering their effects on dismantler and shredder profitabilities. Boon et al. [167] and Boon et al. [169] use goal programming to evaluate the materials streams and process profitabilities for several different aluminum-intensive vehicle (AIV) processing scenarios

Gupta and Evans [172] develop a non-preemptive goal programming model for operational planning of closed-loop supply chains considering multiple products and operations associated with the product, subassembly, part and material levels.

Kongar and Gupta [30] develop a goal programming model of a disassembly-to-order system to determine the best combination of the number of each product type to be taken back at the end-of-life and disassembled to meet the demand for items and materials retrieved from them under a variety of physical, financial and environmental constrains so as to achieve the preemptive goals of maximum total profit, maximum sales from materials, minimum number of disposed items, minimum number of stored items, minimum cost of disposal and minimum cost of preparation, in that order.

Harraz and Galal [61] propose a goal programming based methodology to solve a product recovery network design problem involving the determination of the locations for the different facilities and the amount to be allocated to the different end of life (EOL) options. Chaabane et al. [62] develop a goal programming based sustainable supply chain design methodology by considering carbon emissions, suppliers and sub-contractors selection, total logistics costs, technology acquisition and the choice of transportation modes.
Aspiration levels (goals) are considered concise and precise in goal programming. However, there are many occasions that a decision maker cannot specify the goal values precisely. Fuzzy goal programming takes this uncertainty into consideration by employing the concept of membership functions based on fuzzy set theory [203].

Kongar et al. [11] and Kongar and Gupta [152] use fuzzy goal programming to solve the disassembly-to-order problem defined in Section 1. Mehrbod et al. [69] first develop a multi-objective mixed-integer nonlinear programming formulation for a closedloop supply chain. Then, this model is solved using interactive fuzzy goal programming (IFGP) which has the ability of addressing the imprecise nature of decision-makers' aspiration levels for goals. Ghorbani et al. [77] develop a fuzzy goal programming model for the design of a reverse logistics network. Imtanavanich and Gupta [13] employ weighted fuzzy goal programming to solve the multi-period DTO problem. Imtanavanich and Gupta [17] integrate genetic algorithms with weighted fuzzy goal programming to solve a similar DTO problem.

\subsection{Physical programming}

Physical programming uses a preference function to represent the decision maker's preference. In physical programming, DM determines a suitable preference function and specifies ranges of different degrees of desirability (desirable, tolerable, undesirable, etc.) for each criterion. There are eight preference functions classified into 8 classes, 4 soft and 4 hard [12,204].

The analysis of the literature showed that the physical programming approach has been mostly used for the network design of reverse and closed-loop supply chains and for planning problems in disassembly-to-order (DTO) systems.

In Pochampally et al. [48], linear physical programming (LPP) is employed to identify potential facilities from a set of candidate recovery facilities operating in a region by considering several criteria (viz., quality of products at recovery facility, ratio of throughput to supply of used products, multiplication of throughput by disassembly time, and customer service rating of the recovery facility). Pochampally and Gupta [49] develop an LPP-based reverse supply chain design methodology involving three phases. Economical products to be re-processes are selected from a set of candidate cores in phase I. Phase 2 involves the determination of potential recovery facilities using the criteria and classes defined in Pochampally et al. [48]. Phase 3 determines the right mix and quantities of products to be transported in the reverse supply chain. The strategic and tactical planning model developed by Nukala and Gupta [51] determines the following variables simultaneously: the most economical used-product to re-process, efficient production facilities and the right mix and quantity of goods to be transported across the supply chain. Similar models are presented in Pochampally et al. [54,84] and Ilgin and Gupta [67].

Quality function deployment (QFD) and LPP are integrated in Pochampally et al. [57] to measure the "satisfaction level" of a reverse/closed-loop supply chain with respect to various performance measures such as reputation and innovation. Pochampally et al. [58] present a similar model.

An LPP-based methodology for collection center selection problem is presented in Pochampally and Gupta [68] considering eight criteria (viz., sigma level (SL), per capital income of people in residential area (PR), utilization of incentives from local government (UG), distance from residential area (DR), distance from highways (DH), incentives from local government (IG), space cost (SC), labor cost (LC)).

An LPP model is developed in Kongar and Gupta [205] to solve a disassembly to order problem which involves the determination of the number of items to be disassembled for remanufacturing, 
recycling, storage and disposal. The criteria considered include average customer satisfaction, average quality achievement, resale revenue, recycling revenue, total profit, number of recycled items, average environmental damage, average environmental benefit and number of disposed items. Lambert and Gupta [12] present a similar model. A DTO problem is modeled by Kongar and Gupta [24] considering five goals (number of disposed items, total profit, number of recycled items, environmental damage and customer satisfaction). In Imtanavanich and Gupta [16], LPP is used to solve a multi-period DTO problem. Genetic algorithms and LPP are integrated in Imtanavanich and Gupta [15] to solve a DTO problem. The fitness value of GA is calculated using LPP. A multi-period DTO problem with four objectives (viz., maximization of profit, minimization of procurement cost, minimization of purchase cost and minimization of disposal cost) is solved in Massoud and Gupta [28] by developing an LPP-based solution approach. Optimum disassembly, refurbishment, disposal, recycling and storage plans are determined by the LPP model developed by Ondemir and Gupta [31] for a demand-driven environment utilizing the life-cycle data collected, stored and delivered by sensors and RFID tags. Ondemir and Gupta [46] develop an LPP model to optimize a multi-criteria advanced repair-to-order and disassembly-to-order system involving sensor embedded products.

\subsection{Heuristics and metaheuristics}

A heuristic can be defined as a technique which seeks or finds good solutions to a difficult model. A meta-heuristic extends the heuristic concept by exploiting ideas and concepts from another discipline to help solve the artificial system being modeled. Genetic algorithms, simulated annealing and tabu search are the most commonly used metaheuristics [206]. In this section, we provide an overview of multi objective heuristic and metaheuristic approaches developed to solve ECMPRO related problems.

Gupta and Taleb [5] and Taleb and Gupta [6] presented a heuristic methodology for disassembling multiple product structures with parts/materials commonality. There are two companion algorithms in this methodology: the "Core Algorithm" and the "Allocation Algorithm". The total disassembly requirements of the root items over the planning horizon are determined by the "Core Algorithm" and the schedule for disassembling the roots and the subassemblies are provided by "Allocation Algorithm". Langella [19] extends this methodology by considering holding costs and external procurement of items.

Genetic algorithms (GA) are numerical optimization algorithms inspired by both natural selection and natural genetics. They are generally used to search large, non-linear search spaces where expert knowledge is lacking or difficult to encode and where traditional optimization methods fall short [207]. GAs are by far the most frequently used metaheuristic to solve ECMPRO related problems. Jun et al. [153] develop a multi-objective evolutionary algorithm to determine the best EOL option. In Hula et al. [149], multi objective GA is used to determine the most appropriate EOL option. The green supply chain partner selection problem is solved in Yeh and Chuang [197] by developing two multi objective genetic algorithms. The multi-objective genetic algorithm developed by Sakundarini et al. [139] considers technical, economic and recyclability requirements for the selection of materials with high recyclability. Rickli and Camelio [36] develop a multi-objective genetic algorithm to optimize partial disassembly sequences based on disassembly operation costs, recovery reprocessing costs, revenues and environmental impacts. Chern et al. [194] develop a heuristic called genetic algorithms based master planning algorithm (GAMPA) which solves the master planning problem of a supply chain network involving multiple final products, substitutions, and a recycling process. Liu and Huang [195] use multi objective genetic algoritms to solve two scheduling problems involving economic and environment-related criteria. Wang et al. [80] present an application of multi-objective genetic algorithms in closed-loop supply chain network design.

Besides GAs, researchers have applied several other metaheuristics to ECMPRO related problems. Guo et al. [32] propose a multi-objective scatter search algorithm to solve the selective disassembly problem which involves the determination of optimal disassembly sequences for single or multiple target components. Jamshidi et al. [66] develop a mathematical model for the design of a supply chain by simultaneously considering cost and anvironmental effect. A memetic algorithm integrated with the Taguchi method is utilized to solve the model.

Disassembly Line Balancing Problem (DLBP) is an important and actively researched problem in ECMPRO (see McGovern and Gupta [208] for more information on DLBP). It is a multi-objective problem as described by Gungor and Gupta [209] and has been mathematically proven to be NP-complete by McGovern and Gupta [20] which makes the desire to achieve the best balance computationally expensive when considering large sized problems. Thus, the need to obtain near optimal solutions efficiently have led various authors to use a variety of heuristic and metaheuristic techniques such as

- genetic algorithms (GA) [20,37],

- ant colony optimization (ACO) [21,41],

- simulated annealing (SA) [43],

- tabu search (TS) [45],

- artificial bee colony (ABC) [42],

- particle swarm optimization (PSO) [40],

- river formation dynamics (RFD) [44].

Battaia and Dolgui [210] and Delorme et al. [211] present an overview of multi-objective approaches developed for the design of assembly and disassembly lines.

\subsection{Integration of simulation and optimization techniques}

Simulation is generally employed to analyze complex processes or systems. It involves the development and analysis of models that have the ability of imitating the behavior of the system being analyzed [212].

Shokohyar and Mansour [76] deal with the electronic waste management problem of Iran by developing a simulationoptimization model which determines the locations for collection centers and recycling plants. Fuzzy controlled agent based simulation framework proposed by Zhang et al. [107] evaluates the environmental performance of the suppliers.

\section{Multi-criteria analysis techniques}

While the multi-objective optimization techniques search for new solutions in solution space, multi-criteria analysis techniques consider limited number of predetermined alternatives and discrete preference ratings [201]. In this section, we present such techniques as analytical hierarchy process, fuzzy analytical hierarchy process, analytical network process, data envelopment analysis, DEMATEL, TOPSIS, ELECTRE, PROMETHEE, multi attribute utility theory, VIKOR, MACBETH, case based reasoning, gray relational analysis, and others.

\subsection{Analytical hierarchy process}

The analytical hierarchy process (AHP) is a multi-criteria decision making tool formalized by Saaty [213]. It uses simple 
mathematics to support decision makers in explicitly weighing tangible and intangible criteria against each other for the purpose of resolving conflict or setting priorities.

Azzone and Noci [173] use AHP to evaluate the environmental performance of alternative product designs. In Choi et al. [176], the relative importance of five design for environment strategies are compared using AHP. Wang et al. [180] develop an AHP-based green product design selection methodology which does not require the designers to conduct detailed analysis (e.g., life-cycle assessment) for every new product option. Kim et al. [138] employ AHP to evaluate the recycling potential of materials based on environmental and economic factors.

Noci [104] proposes a green vendor rating system using AHP. Handfield et al. [105] develop an AHP-based methodology to assess the relative performance of several suppliers considering environmental issues. Dai and Blackhurst [130] develop a four-phase methodology for sustainable supplier assessment by integrating quality function deployment (QFD) and AHP. First, customer requirements are linked with the company's sustainability strategy. Then the sustainable purchasing competitive priority is determined. Next, sustainable supplier assessment criteria are developed. Finally, AHP is employed to assess the suppliers. Shaik and Abdul-Kader [185] first develop a reverse logistics performance measurement system which is based on balanced score card and performance prism. Then, AHP is integrated with this system to calculate the overall comprehensive performance index (OCPI).

Barker and Zabinsky [59] use sensitivity analysis with AHP to provide insights into the preference ordering among eight alternative reverse logistics network configurations. In Jiang et al. [140], AHP is used for remanufacturing portfolio selection. Ziout et al. [147] develop an AHP-based methodology to evaluate the sustainability level of manufacturing systems. The AHP-based methodology proposed by Sarmiento and Thomas [96] identifies improvement areas in the implementation of green initiatives. Subramoniam et al. [141] use AHP to validate the Reman DecisionMaking Framework (RDMF) developed in Subramoniam et al. [214].

\subsection{Fuzzy analytical hierarchy process}

There are two characteristics of AHP often criticized in the literature: use of unbalanced scale of judgments and its inability to adequately handle the inherent uncertainty and imprecision in the pair-wise comparison process [215]. Fuzzy analytical process which integrates AHP with the concepts of fuzzy set theory is often used by reserachers to overcome these limitations of AHP.

AHP and fuzzy multi attribute decison making are integrated in the environmentally conscious design methodology proposed by Kuo et al. [175]. Li et al. [177] integrate AHP and fuzzy logic to determine an optimal modular formulation in modular product design with environmental considerations.

Yu et al. [168] use fuzzy AHP to determine the most appropriate recycling option for EOL products considering three criteria: environmental impact, recycling associated cost and recoverable material content.

In Lu et al. [111], Lee et al. [116], Grisi et al. [121], Ciftci and Buyukozkan [127] and Amin and Zhang [131], fuzzy AHP is used to integrate environmental factors into supplier evaluation process. Lee et al. [132] propose a fuzzy AHP based approach to determine the most important criteria for green supplier selection in the Taiwanese hand tool industry. In Chiou et al. [95], fuzzy AHP is employed to compare the green supply chain management (GSCM) practices of American, Japanese and Taiwanese electronics manufacturers operating in China. Chiou et al. [98] employ fuzzy AHP to select the most important criteria in reverse logistics implementation. Efendigil et al. [82] present an approach integrating fuzzy AHP and artificial neural Networks for the third party reverse logistics provider selection problem.

Gupta and Nukala [50] use fuzzy AHP to identify potential facilities in a set of candidate recovery facilities operating in a region. Shaverdi et al. [100] employ fuzzy-AHP to determine the effective factors associated with the sustainable supply chain management in publishing industry.

De Felice and Petrillo [184] integrate AHP and simulation to simultaneously improve the performance of inventory management and reverse logistics management.

The approach proposed by Punniyamoorty et al. [134] combines AHP and structural equation modeling (SEM) for the selection of suppliers considering economic as well as environmental factors.

Thongchattu and Siripokapirom [124] model the green supplier selection problem using AHP. Neural Networks are used to determine criteria weights.

\subsection{Analytical network process}

Analytical network process (ANP) was developed by Saaty [216] as a generalization of AHP. It releases the restrictions of hierarchical AHP structure by modeling the decision problem as an influence network of clusters and nodes contained within the clusters.

ANP is used in Cheng and Lee [85] for investigating the relative importance of service requirements as well as selecting an appropriate third party reverse logistics provider. Meade and Sarkis [81] employ ANP for the evaluation and selection of third party reverse logistics providers. Hsu and $\mathrm{Hu}$ [110] and Hsu and $\mathrm{Hu}$ [115] integrate hazardous substance management to supplier selection using analytical network process (ANP). Büyüközkan and Çiftçi [97] use fuzzy ANP to evaluate green supply chain management practices of an automotive company. Büyüközkan and Çiftçi [126] propose a fuzzy ANP based methodology for sustainable supplier selection.

Ravi et al. [151] use ANP together with BSC to determine the most suitable EOL option for EOL computers. Chen et al. [160] solve green supply chain management strategy selection problem of a Taiwanese electronics company using ANP.

Sarkis [142] employs ANP to evaluate environmentally conscious business practices. In Vinodh et al. [145], environmentally conscious business practice model proposed by Sarkis [142] is adopted for the evaluation of sustainable business practicess in an Indian relays manufacturing organization. Chen et al. [155] use ANP to evaluate several green supply chain management strategies (viz., green design, green purchasing, green marketing, green manufacturing). Bhattacharya et al. [186] develop an intra-organizational collaborative decision-making (CDM) approach for performance measurement of a green supply chain (GSC) by integrating fuzzy ANP and balanced score card. Tuzkaya and Gulsun [55] integrate ANP with fuzzy TOPSIS to evaluate centralized return centers in a reverse logistics network.

Gungor [174] develops an ANP-based methodology to evaluate connection types in design for disassembly.

Govindan et al. [91] develop a two-phase model for the selection of third party reverse logistics providers. In this model, AHP is employed to identify the most prioritized factors while ANP is used to select the reverse logistic providers.

\subsection{Data envelopment analysis}

Data envelopment analysis (DEA) is used to evaluate the performance of a set of peer entities called Decision Making Units (DMUs) which convert multiple inputs into multiple outputs [217].

Kumar and Jain [122] develop a DEA model of green supplier selection by considering carbon footprints of suppliers as a necessary dual role factor. Mirhedayatian et al. [188] evaluate the performance of green supply chains by developing a network DEA 
model involving dual-role factors, undesirable outputs and fuzzy data.

The data envelopment analysis based methodology proposed by Saen [84] determines the most efficient third party reverse logistics (3PL) provider considering quantitative and qualitative data. Saen [86] proposes a DEA based third party reverse logistic provider selection methodology for the case of multiple dual factors while Saen [87] and Azadi and Saen [88] provide 3PL selection models involving both multiple dual factors and imprecise data. Zhou et al. [89] develop a fuzzy confidence DEA model to select third-party recyclers.

Wen and Chi [125] integrate AHP/ANP with DEA for developing a green supplier selection procedure. First, DEA distinguishes the efficient candidates of suppliers from the entire group. Then, AHP/ANP is used for further analysis without making efforts on unnecessary suppliers.

Sarkis [143] integrates ANP and data envelopment analysis (DEA) to evaluate environmentally conscious manufacturing programs. Kuo and Lin [133] develop a methodology by coupling ANP and DEA for green supplier selection.

\subsection{DEMATEL}

DEMATEL (Decision Making and Evaluation Laboratory) method is used to identify causal relationships among the elements of a system. The main output of this technique is a causal diagram which uses digraphs instead of directionless graphs to describe the contextual relationships and the strengths of influence among the elements [218].

Lin [101] uses fuzzy-DEMATEL to analyze the interrelationships among three issues (green supply chain management practices, organizational performance and external driving factors) associated with green supply chain management implementation.

\subsection{TOPSIS}

TOPSIS (Technique for Order Preference by Similarity to Ideal Solution) determines the best alternative based on the concept of compromise solution which has the shortest distance from the ideal solution and the greatest distance from the negative ideal solution in an Euclidean sense [201].

Gupta and Pochampally [170] propose a fuzzy-TOPSIS based approach for the evaluation of recycling programs with respect to drivers of public participation. Remery et al. [161] propose a TOPSIS-based end of life option selection methodology called ELSEM while Wadhwa et al. [156] use fuzzy TOPSIS for option selection problem in reverse logistics. Gao et al. [178] construct a fuzzy TOPSIS model to evaluate a set of feasible green design alternatives. A fuzzy TOPSIS approach is proposed in Yeh and $\mathrm{Xu}$ [171] for the evaluation of alternative recycling activities of a recycling company considering various sustainability criteria with environmental, economic, and social dimensions. Vinodh et al. [181] use fuzzy TOPSIS to determine the best sustainable concept among five sustainable concepts (viz., design for environment, life cycle assessments, environmental conscious quality function deployment, theory of inventive problem solving and life cycle impact assessment). Mahapatara et al. [162] develop a fuzzy TOPSIS methodology to evaluate different reverse manufacturing alternatives (remanufacturing, reselling, repairing, cannibalisation and Refurbishing). Diabat et al. [146] develop a fuzzy-TOPSIS-based methodology to assess the importance of GSCM practices and performances in an automotive company.

Kannan et al. [83] integrate interpretive structural modeling and fuzzy TOPSIS in order to select the best third party reverse logistics provider. Awasthi et al. [120], Govindan et al. [219] and Shen et al.
[137] use fuzzy TOPSIS to generate an overall performance score for measuring the environmental performance of suppliers.

Wittstruck and Teuteberg [193] integrate fuzzy AHP and TOPSIS for recycling partner selection. Senthil et al. [99] determine the best reverse logistics operating channel by combining AHP and fuzzy TOPSIS. Wang and Chan [102] integrate fuzzy TOPSIS and AHP for the evaluation of new green initiatives. In Ravi [90] and Senthil et al. [93], AHP-TOPSIS integration is employed for the selection of third party reverse logistics providers.

\subsection{ELECTRE}

ELECTRE (ELimination Et Choix Traduisant la REalité (in French) which means, elimination and choice expressing reality) performs pair-wise comparisons among alternatives for each one of the attributes separately to establish outranking relationships between the alternatives [220]. These outranking relations are built in such a way that it is possible to compare alternatives. The information required by ELECTRE consists of information among the criteria and information within each criterion [221].

Bufardi et al. [150] employ ELECTRE III for the selection of the best EOL alternative.

\subsection{PROMETHEE}

PROMETHEE (preference ranking organization method for enrichment evaluation) is a prescriptive method that enables a decision maker to rank the alternatives according to the his/her preferences. It requires a preference function associated with each criterion as well as weights indicating their relative importance. While the PROMETHEE I gives partial ranking of alternatives PROMETHEE II gives a complete ranking [222,223].

Avikal et al. [35] develop a PROMETHEE based methodology for assigning the disassembly tasks to workstations of a disassembly line. Ghazilla et al. [39] use PROMETHEE to evaluate alternative fasteners in design for disassembly.

Avikal et al. [34] solve the disassembly line balancing problem by developing an AHP-TOPSIS based methodology. In the proposed heuristic, the important criteria, which play a significant role in the product disassembly process, are selected. Then AHP is applied to calculate the weight of each criterion. Finally, PROMETHEE uses these weights to determine the ranking of the tasks for the assignment to the disassembly stations. Avikal et al. [38] modify Avikal et al.'s methodology [34] by using fuzzy AHP instead of AHP.

Tuzkaya et al. [118] evaluate the environmental performance of suppliers by developing a methodology that integrates fuzzy ANP and Fuzzy PROMETHEE.

\subsection{Multi attribute utility theory (MAUT)}

In multi attribute utility theory, decision maker represents a complex problem as a simple hierarchy and subjectively evaluates a large number of quantitative and qualitative factors considering risk and uncertainty. It can be used in both deterministic and stochastic decision environments [224].

Erol et al. [182] integrate fuzzy entropy and fuzzy multiattribute utility (FMAUT) to measure the sustainability performance of a supply chain. First, fuzzy entropy method is used to determine the importance levels for the indicators. Then, fuzzy MAUT is utilized to calculate the aggregated performance indices with respect to each aspect of sustainability. Shaik and Abdul-Kader [128] present use MAUT to develop an integrated and comprehensive framework for green supplier selection by considering traditional aspects as well as the environmental and the social factors. 


\subsection{VIKOR}

VIKOR (VlseKriterijumskaOptimizacija I KompromisnoResenje (in Serbian), which means multi-criteria optimization and compromise solution) method determines the compromise ranking-list, the compromise solution, and the weight stability intervals for preference stability of the compromise solution obtained with the initial (given) weights. It is especially useful when there are conflicting criteria in the decision problem [225].

Rao [144] proposes a VIKOR-based methodology for the selection of environmentally conscious manufacturing programs.

The green supplier selection and evaluation methodology developed by Datta et al. [129] integrates VIKOR with an interval-valued fuzzy set. Samantra et al. [163] use the methodology proposed in Datta et al. [129] to determine the best product recovery option.

Sasikumar and Haq [63] propose a two-step methodology for the design of a closed-loop supply chain. First, VIKOR is used to select the best third-party reverse logistics provider (3PRLP). Then, a mixed integer linear programming model is developed to make decisions on raw material procurement, production and distribution.

\subsection{MACBETH}

MACBETH (Measuring Attractiveness by a Categorical Based Evaluation Technique) is a technique similar to AHP. The only difference is that MACBETH uses an interval scale while AHP adopts a ratio scale [226].

Dhouib [164] proposes a fuzzy MACBETH methodology to evaluate options in reverse logistics for waste automobiles tires.

\subsection{Case based reasoning}

Case based reasoning is based on a memory-centered cognitive model. In this method, a reasoner remembers a previous situation similar to the current one and uses that to solve the new problem $[227,228]$.

Zeid et al. [7] present a CBR-based methodology to determine the disassembly plan of a single product. Extending Zeid et al. [7], Gupta and Veerakamolmal [9] and Veerakamolmal and Gupta [10] develop CBR approaches to automaticaly generate disassembly plans for multiple products.

Humphreys et al. [106] consider environmental factors in supplier selection process by developing a knowledge-based system (KBS) which integrates case-based reasoning (CBR) and decision support components.

Kuo [179] integrates AHP and CBR to simplify the calculation of recyclability index which is used to evaluate the recyclability of an EOL product. Ghazalli and Murata [159] integrate AHP and CBR to evaluate EOL options for parts and components.

\subsection{Gray relational analysis}

In gray relational analysis, simple mathematical relations are used to deal with uncertain, poor and incomplete information. It solves multi attribute decision making problems by combining the entire range of performance attribute values being considered for every alternative into one, single value [229].

Chan [154] employs gray relational analysis to rank the product EOL options under uncertainty with respect to several criteria at the material level. Li and Zhao [117] integrate threshold method and the gray correlation analysis for the selection of green suppliers. In Chen et al. [119], fuzzy logic and gray relational analysis are integrated to determine suitable suppliers by considering various environment-related criteria.
In Dou et al. [196], analytical network process and gray relational analysis are integrated to determine effective green supplier development programs.

\subsection{Other techniques}

Zareinejad and Javanmard [92] develop an integrated methodology for third-party reverse logistics provider selection. First, relationships among the attributes are analyzed using analytic network process (ANP). Then, intuitionistic fuzzy set (IFS) and gray relation analysis (GRA) are integrated in order to determine the most suitable third party reverse logistics provider under uncertain conditions.

Hsu et al. [183] develop a balanced score card to measure the sustainable performance in semiconductor industry. Fuzzy Delphi method and ANP are used to identify the related measures and perspectives of sustainable balanced score card activities.

Hsu et al. [135] combine DEMATEL, ANP and VIKOR to solve the recycled material vendor selection problem. First, DEMATEL and ANP are integrated to determine the degrees of influence among the criteria. Then, VIKOR is employed to rank the alternative vendors.

Yang and $\mathrm{Wu}$ [112] employ gray entropy method for green supplier selection problem while Yu-zhong and Li-yun [113] solve the same problem using extension method based on entropy weight. Humphreys et al. [108] use dynamic fuzzy membership functions to select green supplies. Feyzioglu and Büyüközkan [123] employ 2 -additive Choquet integral to consider criteria dependencies in green supplier evaluation.

Rao and Padmanabhan [158] use digraph and matrix methods for the selection of best product end-of-life scenario. Bereketli et al. [190] evaluate alternative waste treatment strategies for electrical and electronic equipments using fuzzy LINMAP (linear programming technique for multidimensional analysis of preference). Iakovou et al. [157] develop a multi-criteria analysis technique called multi-criteria matrix to rank components according to their potential value at the end of their useful life. In Lee et al. [148], a multi objective methodology has been developed to determine an appropriate end-of-life option for a product based on the minimization of environmental impact and the costs associated with collection, recovery (e.g., remanufacturing, recycling) and disposal. Sangwan [187] develop a multi-criteria performance analysis tool to evaluate the performance of manufacturing systems based on environmental criteria. Mangla et al. [103] use interpretive structural modeling to analyze the interaction among the various green supply chain enablers/barriers (e.g., supplier commitment, cost, regulations).

\section{Integration of multi-objective optimization techniques with multi-criteria analysis}

This section presents an overview of the studies which integrate the multi-objective optimization techniques with multi-criteria analysis.

Walther et al. [191] present a two-step methodology for the evaluation of alternative scrap treatment systems. First, linear programming or weighted goal programming is used to determine short-term decisions. Then, the results obtained in the first step are used as a priori information for multi-criteria decision making tool, PROMETHEE at strategic level.

Nukala and Gupta [109] employ ANP-GP integration for the supplier selection problem of a closed-loop supply chain. First, the supply chain strategy is determined qualitatively by evaluating the suppliers with respect to several criteria. Then preemptive goal programming taking ANP ratings as input is used to determine the optimal quantities to be ordered from the suppliers. 
In Ravi et al. [94], an integrated ANP-GP methodology is used to select reverse logistics projects. Following the determination of the level of interdependence among the criteria and candidate reverse logistics projects using ANP, zero-one goal programming determines the allocation of resources among reverse logistics projects by considering resource limitations and several other selection constraints.

Dehghanian and Mansour [56] integrate AHP and genetic algorithms for the recovery network design of scrap tires. In the proposed methodology, first, AHP is used to calculate social impacts. Then the Pareto-optimal solutions are determined by using a multi-objective genetic algorithm (MOGA).

Vadde et al. [192] analyze the pricing decisions of product recovery facilities by integrating multi-objective mathematical programming, genetic algorithms and AHP. The weights used in the objective function of the genetic algorithm designed to solve the multi-objective mathematical programming model are determined using AHP. Ge [114] integrates GA and AHP for the evaluation of green suppliers.

Pochampally and Gupta [53] develop a three-phase methodology for the effective design of a reverse supply chain network. The most economical product to reprocess from a set of different used products is selected in phase 1 using a fuzzy benefit function. AHP and fuzzy set theory are employed in phase 2 to identify potential facilities in a set of candidate recovery facilities. Phase III solves a single-period and single-product discrete location model to minimize overall cost across the reverse supply chain network.

Nukala and Gupta [52] integrate Taguchi loss functions, AHP and fuzzy programming to evaluate the suppliers and determine the order quantities in a closed-loop supply chain network. First, Taguchi loss functions quantify the suppliers attributes to quality loss. Then AHP is used to transform these quality losses into a variable that is used in the formulation of the fuzzy programming objective function. Finally, fuzzy programming determines the order quantities.

Buyukozkan and Berkol [60] integrate ANP, goal programming and quality function deployment to design a sustainable supply chain. ANP is employed to determine the importance levels in the house of qualiy by considering the interrelationships among the design requirements and customer requirements while zeroone goal programming is used to select the most suitable design requirements based on ANP results.

Paksoy et al. [65] first propose a fuzzy programming model with multiple objectives for the design of a closed-loop supply chain network. Then, various multi criteria techniques (viz., AHP, fuzzy AHP and fuzzy TOPSIS) are applied to weight the objectives and the corresponding results are discussed.

Kannan et al. [136] propose an integrated approach for supplier selection and order allocation in a green supply chain. First, the relative weights of supplier selection criteria are calculated using fuzzy AHP; then, fuzzy TOPSIS is employed to rank suppliers based on the selected criteria. Finally, MOLP model determines the optimal order quantity from each supplier using the weights of the criteria and ranks of suppliers.

\section{Conclusions}

In this paper, we presented a review of the state of the art literature on the use of multi-criteria decision making techniques in environmentally conscious manufacturing and product recovery (ECMPRO). The MCDM techniques were presented by category, i.e.; multi-objective optimization, multi-criteria analysis and the integration between them. The following general conclusions can be drawn from our literature review.
Since ECMPRO initiatives have economic and environmental consequences, majority of the studies simultaneously consider economic and environmental criteria. The most commonly used environmental criteria include green product design, reduction of material and energy use, use of environment friendly technology, pollution control, environmental management system, green purchasing, green packaging and hazardous substance management system.

There is a significant increase in the number of publications concerning the use of MCDM techniques for ECMPRO problems in recent years. This can be attributed to the increasing popularity of environmental issues among researchers.

Multi-criteria analysis is more popular than multi-objective optimization in ECMPRO. Among the most frequently used techniques, one can find AHP, ANP and TOPSIS. On the other hand, the use of other techniques as MACBETH, DEMATEL, ELECTRE, PROMETHEE is surprisingly rare.

Although simulation is very good at modeling complex systems, its integration with MCDM techniques for the solution of ECMPRO related problems is limited to a few studies. Hence, there are opportunities to develop multi objective solution methodologies integrating simulation with qualitative and/or quantitative MCDM techniques to solve complex ECMPRO issues such as disassembly planning, reverse logistics and CLSC design.

\section{References}

[1] Ilgin MA, Gupta SM. Environmentally conscious manufacturing and product recovery (ECMPRO): a review of the state of the art. J Environ Manag 2010;91:563-91

[2] Bentaha ML, Battaia O, Dolgui A, Hu SJ. Dealing with uncertainty in disassembly line design. CIRP Ann - Manuf Technol 2014;63:21-4.

[3] Bentaha ML, Battaia O, Dolgui A. Disassembly line balancing and sequencing under uncertainty. Procedia CIRP 2014;15:239-44.

[4] Bentaha ML, Battaia O, Dolgui A. Lagrangian relaxation for stochastic disassembly line balancing problem. Procedia CIRP 2014;17:56-60.

[5] Gupta SM, Taleb K. An algorithm to disassemble multiple product structures with multiple occurrence of parts. In: Proceedings of the International Seminar on Reuse. 1996. p. 153-62.

[6] Taleb KN, Gupta SM. Disassembly of multiple product structures. Comput Ind Eng 1997;32:949-61

[7] Zeid I, Gupta SM, Bardasz T. A case-based reasoning approach to planning for disassembly. J Intell Manuf 1997;8:97-106.

[8] Kongar E, Gupta SM. A goal programming approach to the remanufacturing supply chain model. In: Proceedings of the SPIE International Conference on Environmentally Conscious Manufacturing. 2000. p. 167-78.

[9] Gupta SM, Veerakamolmal P. A case-based reasoning approach for optima planning of multi-product/multi-manufacturer disassembly processes. Int J Environ Conscious Des Manuf 2000;9:15-25.

[10] Veerakamolmal P, Gupta SM. A case-based reasoning approach for automating disassembly process planning. J Intell Manuf 2002;13:47-60.

[11] Kongar E, Gupta SM, Al-Turki YAY. A fuzzy goal programming approach to disassembly planning. In: The 6th Saudi Engineering Conference. 2002. p. $561-79$.

[12] Lambert AJD, Gupta SM. Disassembly modeling for assembly, maintenance reuse, and recycling. Boca Raton, FL: CRC Press; 2005.

[13] Imtanavanich P, Gupta SM. Weighted fuzzy goal programming approach for a disassembly-to-order system. In: Proceedings of the 2005 POMS-Boston Meeting. 2005

[14] Imtanavanich P, Gupta SM. Calculating disassembly yields in a multicriteria decision-making environment for a disassembly-to-order system. In: Lawrence KD, Klimberg RK, editors. Applications of management science: in productivity, finance, and operations. 2006. p. 109-25.

[15] Imtanavanich P, Gupta SM. Evolutionary computation with linear physica programming for solving a disassembly-to-order system. In: Proceedings of the SPIE International Conference on Environmentally Conscious Manufacturing VI. 2006. p. 30-41.

[16] Imtanavanich P, Gupta SM. Linear physical programming approach for a disassembly-to-order system under stochastic yields and product's deterioration. In: Proceedings of the 2006 POMS Meeting. 2006. p. 004-213.

[17] Imtanavanich P, Gupta SM. Solving a disassembly-to-order system by using genetic algorithm and weighted fuzzy goal programming. In: Proceedings of the SPIE International Conference on Environmentally Conscious Manufacturing VI. 2006. p. 54-6.

[18] McGovern S, Gupta SM. Ant colony optimization for disassembly sequencing with multiple objectives. Int J Adv Manuf Technol 2006;30:481-96. 
[19] Langella IM. Heuristics for demand-driven disassembly planning. Comput Oper Res 2007;34:552-77.

[20] McGovern SM, Gupta SM. A balancing method and genetic algorithm for disassembly line balancing. Eur J Oper Res 2007;179:692-708.

[21] Agrawal S, Tiwari MK. A collaborative ant colony algorithm to stochastic mixed-model U-shaped disassembly line balancing and sequencing problem. Int J Prod Res 2008;46:1405-29.

[22] McGovern SM, Gupta SM. Lexicographic goal programming and assessment tools for a combinatorial production problem. In: Bui LT, Alam S, editors. Multi-objective optimization in computational intelligence: theory and practice. IGI Global; 2008. p. 148-84.

[23] Lu C, Huang HZ, Fuh JYH, Wong YS. A multi-objective disassembly planning approach with ant colony optimization algorithm. Proc Inst Mech Eng B: J Eng Manuf 2008;222:1465-74.

[24] Kongar E, Gupta SM. Solving the disassembly-to-order problem using linear physical programming. Int J Math Oper Res 2009;1:504-31.

[25] Xanthopoulos A, Iakovou E. On the optimal design of the disassembly and recovery processes. Waste Manag 2009;29:1702-11.

[26] Ding L-P, Feng Y-X, Tan J-R, Gao Y-C. A new multi-objective ant colony algorithm for solving the disassembly line balancing problem. Int J Adv Manuf Technol 2010;48:761-71.

[27] Ding L, Chen W, Tan J, Feng Y. Multi-objective disassembly line balancing via modified ant colony optimization algorithm. In: Proceedings of the 2010 IEEE 5th International Conference on Bio-Inspired Computing: Theories and Applications (BIC-TA 2010). 2010. p. 426-30.

[28] Massoud AZ, Gupta SM. Linear physical programming for solving the multi-criteria disassembly-to-order problem under stochastic yields, limited supply, and quantity discount. In: Proceedings of 2010 Northeast Decision Sciences Institute Conference. 2010. p. 474-9.

[29] Massoud AZ, Gupta SM. Preemptive goal programming for solving the multi-criteria disassembly-to-order problem under stochastic yields, limited supply, and quantity discount. In: Proceedings of the 2010 Northeast Decision Sciences Institute Conference. 2010. p. 415-20.

[30] Kongar E, Gupta SM. A multi-criteria decision making approach for disassembly-to-order systems. J Electron Manuf 2002;11:171-83.

[31] Ondemir O, Gupta SM. Order-driven component and product recovery for Sensor-embedded Products (SEPS) using linear physical programming. In: Proceedings of the 41st International Conference on Computers \& Industrial Engineering. 2011.

[32] Guo X, Liu S, Wang D, Hou C. An improved multi-objective scatter search approach for solving selective disassembly optimization problem. In: Proceedings of the 31st Chinese Control Conference. 2012. p. 7703-8.

[33] Wang HS, Che ZH, Chiang CJ. A hybrid genetic algorithm for multi-objective product plan selection problem with ASP and ALB. Expert Syst Appl 2012;39:5440-50

[34] Avikal S, Mishra PK, Jain R. An AHP and PROMETHEE methods-based environment friendly heuristic for disassembly line balancing problems. Interdiscip Environ Rev 2013;14:69-85.

[35] Avikal S, Mishra PK, Jain R, Yadav HC. A PROMETHEE method based heuristic for disassembly line balancing problem. Ind Eng Manag Syst 2013;12:254-63.

[36] Rickli JL, Camelio JA. Multi-objective partial disassembly optimization based on sequence feasibility. J Manuf Syst 2013;32:281-93.

[37] Aydemir-Karadag A, Turkbey O. Multi-objective optimization of stochastic disassembly line balancing with station paralleling. Comput Ind Eng 2013;65:413-25.

[38] Avikal S, Mishra PK, Jain R. A fuzzy AHP and PROMETHEE methodbased heuristic for disassembly line balancing problems. Int J Prod Res 2014;52:1306-17.

[39] Ghazilla R, Taha Z, Yusoff S, Rashid S, Sakundarini N. Development of decision support system for fastener selection in product recovery oriented design. Int J Adv Manuf Technol 2013;70:1403-13.

[40] Kalayci CB, Gupta SM. A particle swarm optimization algorithm with neighborhood-based mutation for sequence-dependent disassembly line balancing problem. Int J Adv Manuf Technol 2013;69:197-209.

[41] Kalayci CB, Gupta SM. Ant colony optimization for sequence-dependent disassembly line balancing problem. J Manuf Technol Manag 2013;24:413-27.

[42] Kalayci CB, Gupta SM. Artificial bee colony algorithm for solving sequence-dependent disassembly line balancing problem. Expert Syst Appl 2013;40:7231-41.

[43] Kalayci CB, Gupta SM. In: Lawrence KD, Kleinman G, editors. Balancing a sequence-dependent disassembly line using simulated annealing algorithm. Emerald: Appl Manag Sci; 2013. p. 81-103.

[44] Kalayci CB, Gupta SM. River formation dynamics approach for sequencedependent disassembly line balancing problem. In: Gupta SM, editor. Reverse supply chains. Boca Raton, FL: CRC Press; 2013. p. 289-312.

[45] Kalayci CB, Gupta SM. A tabu search algorithm for balancing a sequencedependent disassembly line. Prod Plan Control 2014;25:149-60.

[46] Ondemir O, Gupta SM. A multi-criteria decision making model for advanced repair-to-order and disassembly-to-order system. Eur J Oper Res 2014;233:408-19.

[47] Ondemir O, Gupta SM. Quality management in product recovery using the Internet of Things: an optimization approach. Comput Ind 2014;65:491-504.

[48] Pochampally KK, Gupta SM, Kamarthi SV. Identification of potential recovery facilities for designing a reverse supply chain network using physical programming. In: Proceedings of the SPIE International Conference on Environmentally Conscious Manufacturing III. 2003. p. 139-46.
[49] Pochampally KK, Gupta SM. A linear physical programming approach for designing a reverse supply chain. In: Proceedings of the Fifth International Conference on Operations and Quantitative Management. 2004. p. 261-9.

[50] Gupta SM, Nukala S. A fuzzy AHP-based approach for selecting potential recovery facilities in a closed loop supply chain. In: Proceedings of the SPIE International Conference on Environmentally Conscious Manufacturing V. 2005. p. 58-63.

[51] Nukala S, Gupta SM. Strategic and tactical planning of a closed-loop supply chain network: a linear physical programming approach. In: Proceedings of the 2006 POMS Meeting. 2006. p. 004-210.

[52] Nukala S, Gupta SM. A fuzzy mathematical programming approach for supplier selection in a closed-loop supply chain network. In: Proceedings of the 2007 POMS-Dallas Meeting. 2007.

[53] Pochampally KK, Gupta SM. A multiphase fuzzy logic approach to strategic planning of a reverse supply chain network. IEEE Trans Electron Pack Manufa 2008;31:72-82.

[54] Pochampally KK, Nukala S, Gupta SM. Quantitative decision-making techniques for reverse/closed-loop supply chain design. In: Gupta SM, Lambert AJD, editors. Environment conscious manufacturing. Boca Raton, FL, USA: CRC Press; 2008.

[55] Tuzkaya G, Gulsun B. Evaluating centralized return centers in a reverse logistics network: an integrated fuzzy multi-criteria decision approach. Int J Environ Sci Technol 2008;5:339-52.

[56] Dehghanian F, Mansour S. Designing sustainable recovery network of end-of-life products using genetic algorithm. Resour Conserv Recycl 2009;53:559-70.

[57] Pochampally KK, Gupta SM, Govindan K. Metrics for performance measurement of a reverse/closed-loop supply chain. Int J Bus Perform Supply Chain Model 2009;1:8-32.

[58] Pochampally KK, Nukala S, Gupta SM. Strategic planning models for reverse and closed-loop supply chains. Boca Raton, FL, USA: CRC Press; 2009.

[59] Barker TJ, Zabinsky ZB. A multicriteria decision making model for reverse logistics using analytical hierarchy process. Omega 2011;39:558-73.

[60] Buyukozkan G, Berkol C. Designing a sustainable supply chain using an integrated analytic network process and goal programming approach in quality function deployment. Expert Syst Appl 2011;38:13731-48.

[61] Harraz NA, Galal NM. Design of sustainable end-of-life vehicle recovery network in Egypt. Ain Shams Eng J 2011;2:211-9.

[62] Chaabane A, Ramudhin A, Paquet M. Designing supply chains with sustainability considerations. Prod Plan Control 2011;22:727-41.

[63] Sasikumar P, Haq AN. Integration of closed loop distribution supply chain network and 3PRLP selection for the case of battery recycling. Int J Prod Res 2011;49:3363-85.

[64] Wang F, Lai X, Shi N. A multi-objective optimization for green supply chain network design. Decis Support Syst 2011;51:262-9.

[65] Paksoy T, Pehlivan NY, Ozceylan E. Fuzzy multi-objective optimization of a green supply chain network with risk management that includes environmental hazards. Human Ecol Risk Assess 2012;18:1120-51.

[66] Jamshidi R, Fatemi Ghomi SMT, Karimi B. Multi-objective green supply chain optimization with a new hybrid memetic algorithm using the Taguchi method. Sci Iran 2012;19:1876-86.

[67] Ilgin MA, Gupta SM. Remanufacturing modeling and analysis. CRC Press/Taylor \& Francis: Boca Raton, FL; 2012.

[68] Pochampally KK, Gupta SM. Use of linear physical programming and Bayesian updating for design issues in reverse logistics. Int J Prod Res 2012;50:1349-59.

[69] Mehrbod M, Tu N, Miao L, Wenjing D. Interactive fuzzy goal programming for a multi-objective closed-loop logistics network. Ann Oper Res 2012;201:367-81.

[70] Pishvaee MS, Razmi J. Environmental supply chain network design using multi-objective fuzzy mathematical programming. Appl Math Model 2012;36:3433-46.

[71] Samanlioglu F. A multi-objective mathematical model for the industrial hazardous waste location-routing problem. Eur J Oper Res 2013;226:332-40.

[72] Ramezani M, Bashiri M, Tavakkoli-Moghaddam R. A new multi-objective stochastic model for a forward/reverse logistic network design with responsiveness and quality level. Appl Math Model 2013;37:328-44.

[73] Özkır V, Başlıgil H. Multi-objective optimization of closed-loop supply chains in uncertain environment. J Clean Prod 2013;41:114-25.

[74] Ozceylan E, Paksoy T. Fuzzy multi-objective linear programming approach for optimising a closed-loop supply chain network. Int J Prod Res 2013;51:2443-61.

[75] Ozceylan E, Paksoy T. A mixed integer programming model for a closed-loop supply-chain network. Int J Prod Res 2013;51:718-34.

[76] Shokohyar S, Mansour S. Simulation-based optimisation of a sustainable recovery network for Waste from Electrical and Electronic Equipment (WEEE). Int J Comput Integr Manuf 2013;26:487-503.

[77] Ghorbani M, Arabzad SM, Tavakkoli-Moghaddam R. A multi-objective fuzzy goal programming model for reverse supply chain design. Int J Oper Res 2014;19:141-53.

[78] Mirakhorli A. Fuzzy multi-objective optimization for closed loop logistics network design in bread-producing industries. Int J Adv Manuf Technol 2014;70:349-62.

[79] Nurjanni KP, Carvalho MS, da Costa LAAF. Green supply chain design with multi-objective optimization. In: Proceedings of the 2014 International Conference on Industrial Engineering and Operations Management. 2014. p. 488-97. 
[80] Wang L-C, Tan M-C, Chiang I-F, Chen Y-Y, Lin S-C, Chen ST. Genetic algorithm approach for multi-objective green supply chain design. In: Proceedings of the 2014 International Conference on Industrial Engineering and Operations Management. 2014. p. 2960-8.

[81] Meade L, Sarkis J. A conceptual model for selecting and evaluating third-party reverse logistics providers. Supply Chain Manag 2002; 7:283-95.

[82] Efendigil T, Onut S, Kongar E. A holistic approach for selecting a third-party reverse logistics provider in the presence of vagueness. Comput Ind Eng 2008;54:269-87.

[83] Kannan G, Pokharel S, Sasi Kumar P. A hybrid approach using ISM and fuzzy TOPSIS for the selection of reverse logistics provider. Resour Conserv Recycl 2009;54:28-36.

[84] Saen RF. A mathematical model for selecting third-party reverse logistics providers. Int J Procur Manag 2009;2:180-90.

[85] Cheng Y-H, Lee F. Outsourcing reverse logistics of high-tech manufacturing firms by using a systematic decision-making approach: TFT-LCD sector in Taiwan. Ind Mark Manag 2010;39:1111-9.

[86] Saen RF. A new model for selecting third-party reverse logistics providers in the presence of multiple dual-role factors. Int J Adv Manuf Technol 2010;46:405-10.

[87] Saen RF. A decision model for selecting third-party reverse logistics providers in the presence of both dual-role factors and imprecise data. Asia-Pacific J Oper Res 2011;28:239-54.

[88] Azadi M, Saen RF. A new chance-constrained data envelopment analysis for selecting third-party reverse logistics providers in the existence of dual-role factors. Expert Syst Appl 2011;38:12231-6.

[89] Zhou H, Du G, An T. Selection of optimal third-party logistics recycler based on fuzzy DEA. In: Proceedings of the 2012 International Conference on Automobile and Traffic Science, Materials, Metallurgy Engineering. 2012. p. $146-51$.

[90] Ravi V. Selection of third-party reverse logistics providers for end-of-life computers using TOPSIS-AHP based approach. Int J Logist Syst Manag 2012;11:24-37

[91] Govindan K, Sarkis J, Palaniappan M. An analytic network process-based multicriteria decision making model for a reverse supply chain. Int J Adv Manuf Technol 2013;68:863-80.

[92] Zareinejad M, Javanmard H. Evaluation and selection of a third-party reverse logistics provider using ANP and IFG-MCDM methodology. Life Sci J 2013;10:350-5.

[93] Senthil S, Srirangacharyulu B, Ramesh A. A robust hybrid multi-criteria decision making methodology for contractor evaluation and selection in third-party reverse logistics. Expert Syst Appl 2014;41:50-8.

[94] Ravi V, Shankar R, Tiwari MK. Selection of a reverse logistics project for end-of-life computers: ANP and goal programing approach. Int J Prod Res 2008;46:4849-70

[95] Chiou CY, Hsu CW, Hwang WY. Comparative investigation on green supplier selection of the American, Japanese and Taiwanese electronics industry in China. In: IEEE International Conference on Industrial Engineering and Engineering Management. 2008. p. 1909-14.

[96] Sarmiento R, Thomas A. Identifying improvement areas when implementing green initiatives using a multitier AHP approach. Benchmarking 2010;17:452-63.

[97] Büyüközkan G, Ciftçi G. Evaluation of the green supply chain management practices: a fuzzy ANP approach. Prod Plan Control 2012;23:405-18.

[98] Chiou CY, Chen HC, Yu CT, Yeh CY. Consideration factors of reverse logistics implementation - a case study of Taiwan's electronics industry. Procedia Social Behav Sci 2012:40:375-81.

[99] Senthil S, Srirangacharyulu B, Ramesh A. A decision making methodology for the selection of reverse logistics operating channels. Procedia Eng 2012:38:418-28.

[100] Shaverdi M, Heshmati MR, Eskandaripour E, Tabar AAA. Developing sustainable SCM evaluation model using fuzzy AHP in publishing industry. Procedia Comput Sci 2013;17:340-9.

[101] Lin R-J. Using fuzzy DEMATEL to evaluate the green supply chain management practices. J Clean Prod 2013;40:32-9.

[102] Wang X, Chan HK. A hierarchical fuzzy TOPSIS approach to assess improvement areas when implementing green supply chain initiatives. Int J Prod Res 2013;51:3117-30

[103] Mangla S, Madaan J, Sarma PRS, Gupta MP. Multi-objective decision modelling using interpretive structural modelling for green supply chains. Int J Logist Syst Manag 2014;17:125-42.

[104] Noci G. Designing a green vendor rating systems for the assessment of a supplier's environmental performance. Eur J Purch Supply Manag 1997:3:103-14.

[105] Handfield R, Walton SV, Sroufe R, Melnyk SA. Applying environmental criteria to supplier assessment: a study in the application of the analytical hierarchy process. Eur J Oper Res 2002;141:70-87.

[106] Humphreys P, McIvor R, Chan F. Using case-based reasoning to evaluate supplier environmental management performance. Expert Syst Appl 2003;25:141-53.

[107] Zhang HC, Li J, Merchant ME. Using fuzzy multi-agent decision-making in environmentally conscious supplier management. CIRP Ann - Manuf Technol 2003;52:385-8.

[108] Humphreys P, McCloskey A, Mclvor R, Maguire L, Glackin C. Employing dynamic fuzzy membership functions to assess environmental performance in the supplier selection process. Int J Prod Res 2006;44:2379-419.
[109] Nukala S, Gupta SM. Supplier selection in a closed-loop supply chain network: an ANP-goal programming based methodology. In: Proceedings of the SPIE International Conference on Environmentally Conscious Manufacturing VI. 2006. p. 130-8.

[110] Hsu C-W, Hu AH. Application of analytic network process on supplier selection to hazardous substance management in green supply chain management. In: IEEE International Conference on Industrial Engineering and Engineering Management. 2007. p. 1362-8.

[111] Lu LYY, Wu CH, Kuo TC. Environmental principles applicable to green supplier evaluation by using multi-objective decision analysis. Int J Prod Res 2007:45:4317-31.

[112] Yang Y, Wu L. Grey entropy method for green supplier selection. In: International Conference on Wireless Communications, Networking and Mobile Computing 2007, WiCom 2007. 2007. p. 4682-5.

[113] Yu-zhong Y, Li-yun W. Extension method for green supplier selection. In: 4th International Conference on Wireless Communications. Networking and Mobile Computing 2008, WiCOM '08. 2008. p. 1-4.

[114] Ge Y. Research on green suppliers' evaluation based on AHP \& genetic algorithm. In: 2009 International Conference on Signal Processing Systems. 2009 p. $615-9$.

[115] Hsu C-W, Hu AH. Applying hazardous substance management to supplier selection using analytic network process. J Clean Prod 2009;17: 255-64.

[116] Lee AHI, Kang H-Y, Hsu C-F, Hung H-C. A green supplier selection model for high-tech industry. Expert Syst Appl 2009;36:7917-27.

[117] Li X, Zhao C. Selection of suppliers of vehicle components based on green supply chain. In: 16th International Conference on Industrial Engineering and Engineering Management. 2009. p. 1588-91.

[118] Tuzkaya G, Ozgen A, Ozgen D, Tuzkaya UR. Environmental performance evaluation of suppliers: a hybrid fuzzy multi criteria decision approach. Int J Environ Sci Technol 2009;6:477-90.

[119] Chen CC, Tseng ML, Lin YH, Lin ZS. Implementation of green supply chain management in uncertainty. In: IEEE International Conference on Industrial Engineering and Engineering Management. 2010. p. 260-4.

[120] Awasthi A, Chauhan SS, Goyal SK. A fuzzy multicriteria approach for evaluating environmental performance of suppliers. Int J Prod Econ 2010;126:370-8.

[121] Grisi R, Guerra L, Naviglio G. Supplier performance evaluation for green supply chain management. In: Business performance measurement and management. Berlin, Heidelberg: Springer; 2010. p. 149-63.

[122] Kumar A, Jain V. Supplier selection: a green approach with carbon footprint monitoring. In: International Conference on Supply Chain Management and Information Systems. 2010. p. 1-8.

[123] Feyzioglu O, Büyüközkan G. Evaluation of green suppliers considering decision criteria dependencies. In: Multiple criteria decision making for sustainable energy and transportation systems. Springer; 2010 p. $145-54$.

[124] Thongchattu C, Siripokapirom S. Green supplier selection consensus by neural network. In: 2nd International Conference on Mechanical and Electronics Engineering. 2010. p. 313-6.

[125] Wen UP, Chi JM. Developing green supplier selection procedure: a DEA approach. In: IEEE 17th International Conference on Industrial Engineering and Engineering Management. 2010. p. 70-4

[126] Büyüközkan G, Ciftçi G. A novel fuzzy multi-criteria decision framework for sustainable supplier selection with incomplete information. Comput Ind 2011;62:164-74.

[127] Ciftci G, Buyukozkan G. A fuzzy MCDM approach to evaluate green suppliers Int J Comput Intell Syst 2011;4:894-909.

[128] Shaik M, Abdul-Kader W. Green supplier selection generic framework: a multi-attribute utility theory approach. Int J Sustain Eng 2011;4:37-56.

[129] Datta S, Samantra C, Mahapatra SS, Banerjee S, Bandyopadhyay A. Green supplier evaluation and selection using VIKOR method embedded in fuzzy expert system with intervalvalued fuzzy numbers. Int J Procur Manag 2012;5:647-78

[130] Dai J, Blackhurst J. A four-phase AHP-QFD approach for supplier assessment: a sustainability perspective. Int J Prod Res 2012;50:5474-90.

[131] Amin SH, Zhang G. An integrated model for closed-loop supply chain configuration and supplier selection: multi-objective approach. Expert Syst App 2012;39:6782-91

[132] Lee T-R, Le TPN, Genovese A, Koh LS. Using FAHP to determine the criteria for partner's selection within a green supply chain: the case of hand tool industry in Taiwan. J Manuf Technol Manag 2012;23:25-55.

[133] Kuo RJ, Lin YJ. Supplier selection using analytic network process and data envelopment analysis. Int J Prod Res 2012;50:2852-63.

[134] Punniyamoorty M, Mathiyalagan P, Lakshmi G. A combined application of structural equation modeling (SEM) and analytic hierarchy process (AHP) in supplier selection. Benchmarking 2012;19:70-92.

[135] Hsu CH, Wang F-K, Tzeng G-H. The best vendor selection for conducting the recycled material based on a hybrid MCDM model combining DANP with VIKOR. Resour Conserv Recycl 2012;66:95-111.

[136] Kannan D, Khodaverdi R, Olfat L, Jafarian A, Diabat A. Integrated fuzzy mult criteria decision making method and multi-objective programming approach for supplier selection and order allocation in a green supply chain. J Clean Prod 2013;47:355-67.

[137] Shen L, Olfat L, Govindan K, Khodaverdi R, Diabat A. A fuzzy multi criteria approach for evaluating green supplier's performance in green supply chain with linguistic preferences. Resour Conserv Recycl 2013;74:170-9. 
[138] Kim J, Hwang Y, Park K. An assessment of the recycling potential of materials basedon environmental and economic factors; case study in South Korea. J Clean Prod 2009;17:1264-71.

[139] Sakundarini N, Taha Z, Abdul-Rashid S, Ghazilla R, Gonzales J. Multi-objective optimization for high recyclability material selection using genetic algorithm. Int J Adv Manuf Technol 2013;68:1441-51.

[140] Jiang Z, Zhang H, Sutherland JW. Development of multi-criteria decision making model for remanufacturing technology portfolio selection. J Clean Prod 2012;19:1939-45

[141] Subramoniam R, Huisingh D, Chinnam RB, Subramoniam S. Remanufacturing Decision-Making Framework (RDMF): research validation using the analytical hierarchical process. J Clean Prod 2013;40:212-20.

[142] Sarkis J. Evaluating environmentally conscious business practices. Eur J Oper Res 1998;107:159-74.

[143] Sarkis J. A methodological framework for evaluating environmentally conscious manufacturing programs. Comput Ind Eng 1999;36:793-810.

[144] Rao RV. An improved compromise ranking method for evaluation of environmentally conscious manufacturing programs. Int J Prod Res 2009;47:4399-412.

[145] Vinodh S, Prasanna M, Manoj S. Application of analytical network process for the evaluation of sustainable business practices in an Indian relays manufacturing organization. Clean Technol Environ Policy 2012;14:309-17.

[146] Diabat A, Khodaverdi R, Olfat L. An exploration of green supply chain practices and performances in an automotive industry. Int J Adv Manuf Technol 2013;68:949-61.

[147] Ziout A, Azab A, Altarazi S, ElMaraghy WH. Multi-criteria decision support for sustainability assessment of manufacturing system reuse. CIRP J Manuf Sci Technol 2013;6:59-69.

[148] Lee SG, Lye SW, Khoo MK. A multi-objective methodology for evaluating product end-of-life options and disassembly. Int J Adv Manuf Technol 2001;18:148-56.

[149] Hula A, Jalali K, Hamza K, Skerlos SJ, Saitou K. Multi-criteria decision-making for optimization of product disassembly under multiple situations. Environ Sci Technol 2003;37:5303-13.

[150] Bufardi A, Gheorghe R, Kiritsis D, Xirouchakis P. Multicriteria decisionaid approach for product end-of-life alternative selection. Int J Prod Res 2004;42:3139-57.

[151] Ravi V, Shankar R, Tiwari MK. Analyzing alternatives in reverse logistics for end-of-life computers: ANP and balanced scorecard approach. Comput Ind Eng 2005;48:327-56.

[152] Kongar E, Gupta SM. Disassembly to order system under uncertainty. Omega 2006:34:550-61.

[153] Jun HB, Cusin M, Kiritsis D, Xirouchakis P. A multi-objective evolutionary algorithm for EOL product recovery optimization: turbocharger case study. Int J Product Res 2007;45:4573-94

[154] Chan JWK. Product end-of-life options selection: grey relational analysis approach. Int J Prod Res 2008;46:2889-912.

[155] Chen CC, Shih H-S, Wu K-S, Shyur H-J. Using ANP for the selection of green supply chain management strategies. In: Proceedings of the 10th International Symposium on the Analytic Hierarchy/Network Process. 2009.

[156] Wadhwa S, Madaan J, Chan FTS. Flexible decision modeling of reverse logistics system: a value adding MCDM approach for alternative selection. Robot Comput Integr Manuf 2009;25:460-9.

[157] Iakovou E, Moussiopoulos N, Xanthopoulos A, Achillas C, Michailidis N, Chatzipanagioti $\mathrm{M}$, et al. A methodological framework for end-of-life management of electronic products. Resour Conserv Recycl 2009;53:329-39.

[158] Rao RV, Padmanabhan KK. Selection of best product end-of-life scenario using digraph and matrix methods. J Eng Des 2010;21:455-72.

[159] Ghazalli Z, Murata A. Development of an AHP-CBR evaluation system for remanufacturing: end-of-life selection strategy. Int J Sustain Eng 2011;4:2-15.

[160] Chen C-C, Shih H-S, Shyur H-J, Wu K-S. A business strategy selection of green supply chain management via an analytic network process. Comput Math Appl 2012;64:2544-57.

[161] Remery M, Mascle C, Agard B. A new method for evaluating the best product end-of-life strategy during the early design phase. J Eng Des 2012;23:419-41.

[162] Mahapatara SS, Sharma SK, Parappagoudar MB. A novel multi-criteria decision making approach for selection of reverse manufacturing alternative. Int J Serv Oper Manag 2013;15:176-95.

[163] Samantra C, Sahu NK, Datta S, Mahapatra SS. Decision-making in selecting reverse logistics alternative using interval-valued fuzzy sets combined with VIKOR approach. Int J Serv Oper Manag 2013;14:175-96.

[164] Dhouib D. An extension of MACBETH method for a fuzzy environment to analyze alternatives in reverse logistics for automobile tire wastes. Omega 2014;42:25-32.

[165] Gupta SM, Isaacs JA. Value analysis of disposal strategies for automobiles. Comput Ind Eng 1997;33:325-8.

[166] Isaacs JA, Gupta SM. Economic consequences of increasing polymer content for the U.S. automobile recycling infrastructure. J Ind Ecol 1997;1:19-33.

[167] Boon JE, Isaacs JA, Gupta SM. Economic impact of aluminum-intensive vehicles on the U.S. automotive recycling infrastructure. J Ind Ecol 2000:4:117-34.

[168] Yu Y, Jin K, Zhang HC, Ling FF, Barnes D. A decision-making model for materials management of end-of-life electronic products. J Manuf Syst 2000;19:94-107.

[169] Boon JE, Isaacs JA, Gupta SM. End-of-life infrastructure economics for clean vehicles in the United States. J Ind Ecol 2003;7:25-45.
[170] Gupta SM, Pochampally KK. Evaluation of recycling programs with respect to drivers of public participation: a fuzzy TOPSIS approach. In: Proceedings of the 2004 Northeast Decision Sciences Institute Conference. 2004. p. 226-8.

[171] Yeh C-H, Xu Y. Sustainable planning of e-waste recycling activities using fuzzy multicriteria decision making. J Clean Prod 2013;52:194-204.

[172] Gupta A, Evans GW. A goal programming model for the operation of closedloop supply chains. Eng Optim 2009;41:713-35.

[173] Azzone G, Noci G. Measuring the environmental performance of new products: an integrated approach. Int J Prod Res 1996;34:3055-78.

[174] Gungor A. Evaluation of connection types in design for disassembly (DFD) using analytic network process. Comput Ind Eng 2006;50:35-54

[175] Kuo T-C, Chang S-H, Huang S. Environmentally conscious design by using fuzzy multi-attribute decision-making. Int J Adv Manuf Technol 2006;29:419-25

[176] Choi JK, Nies LF, Ramani K. A framework for the integration of environmental and business aspects toward sustainable product development. J Eng Des 2008; 19:431-46.

[177] Li J, Zhang H-C, Gonzalez MA, Yu S. A multi-objective fuzzy graph approach for modular formulation considering end-of-life issues. Int J Prod Res 2008;46:4011-33.

[178] Gao Y, Liu Z, Hu D, Zhang L, Gu G. Selection of green product design scheme based on multi-attribute decision-making method. Int J Sustain Eng 2010;3:277-91.

[179] Kuo TC. Combination of case-based reasoning and analytical hierarchy process for providing intelligent decision support for product recycling strategies. Expert Syst Appl 2010;37:5558-63.

[180] Wang X, Chan HK, Li D. A case study of AHP based model for green product design selection. In: Proceedings of the EWG-DSS Liverpool - 2012. Workshop on Decision Support Systems and Operations Management Trends and Solutions in Industries. 2012. p. 1-6.

[181] Vinodh S, Mulanjur G, Thiagarajan A. Sustainable concept selection using modified fuzzy TOPSIS: a case study. Int J Sustain Eng 2013;6:109-16.

[182] Erol I, Sencer S, Sari R. A new fuzzy multi-criteria framework for measuring sustainability performance of a supply chain. Ecol Econ 2011;70: 1088-100.

[183] Hsu C-W, Hu AH, Chiou C-Y, Chen T-C. Using the FDM and ANP to construct a sustainability balanced scorecard for the semiconductor industry. Expert Syst Appl 2011;38:12891-9

[184] De Felice F, Petrillo A. Hierarchical model to optimize performance in logistics policies: multi attribute analysis. Procedia - Soc Behav Sci 2012;58:1555-64.

[185] Shaik M, Abdul-Kader W. Performance measurement of reverse logistics enterprise: a comprehensive and integrated approach. Meas Bus Excell 2012;16:23-34.

[186] Bhattacharya A, Mohapatra P, Kumar V, Dey PK, Brady M, Tiwari MK, et al. Green supply chain performance measurement using fuzzy ANP-based balanced scorecard: a collaborative decision-making approach. Prod Plan Control 2014;25:698-714.

[187] Sangwan KS. Evaluation of manufacturing systems based on environmental aspects using a multi-criteria decision model. Int J Ind Syst Eng 2013;14:40-57

[188] Mirhedayatian SM, Azadi M, Saen RF. A novel network data envelopment analysis model for evaluating green supply chain management. Int J Prod Econ 2014:147:544-54.

[189] Bouchery Y, Ghaffari A, Jemai Z, Dallery Y. Including sustainability criteria into inventory models. Eur J Oper Res 2012;222:229-40.

[190] Bereketli I, Erol Genevois M, Esra Albayrak Y, Ozyol M. WEEE treatment strategies' evaluation using fuzzy LINMAP method. Expert Syst Appl 2011;38:71-9.

[191] Walther G, Schmid E, Kramer S, Spengler T. Planning and evaluation of sustainable reverse logistics systems. In: Operations Research Proceedings 2005 Springer; 2006. p. 577-82.

[192] Vadde S, Zeid A, Kamarthi SV. Pricing decisions in a multi-criteria setting for product recovery facilities. Omega 2011;39:186-93.

[193] Wittstruck D, Teuteberg F. Integrating the concept of sustainability into the partner selection process: a fuzzy-AHP-TOPSIS approach. Int J Logist Syst Manag 2012;12:195-226.

[194] Chern C-C, Lei S-T, Huang K-L. Solving a multi-objective master planning problem with substitution and a recycling process for a capacitated multicommodity supply chain network. J Intell Manuf 2013;25:1-25.

[195] Liu C-H, Huang D-H. Reduction of power consumption and carbon footprints by applying multi-objective optimisation via genetic algorithms. Int J Prod Res 2014:52:337-52.

[196] Dou Y, Zhu Q, Sarkis J. Evaluating green supplier development programs with a grey-analytical network process-based methodology. Eur J Oper Res 2014:233:420-31.

[197] Yeh W-C, Chuang M-C. Using multi-objective genetic algorithm for partner selection in green supply chain problems. Expert Syst Appl 2011;38:4244-53.

[198] Tang Y, Zhou M, Zussman E, Caudill R. Disassembly modeling, planning, and application. J Manuf Syst 2002;21:200-17.

[199] Bentaha ML, Battaia O, Dolgui A. An exact solution approach for disassembly line balancing problem under uncertainty of the task processing times. Int J Prod Res 2015;53:1807-18.

[200] Bentaha ML, Battaia O, Dolgui A. A sample average approximation method for disassembly line balancing problem under uncertainty. Comput Oper Res 2014;51:111-22.

[201] Tzeng G-H, Huang JJ. Multiple attribute decision making: methods and applications. Boca Raton, FL: CRC Press; 2011. 
[202] Ignizio JP. Goal programming and extensions. Lexington: Lexington Books; 1976.

[203] Aouni B, Martel J-M, Hassaine A. Fuzzy goal programming model: an overview of the current state-of-the art. J Multi-Criteria Decis Anal 2009;16:149-61.

[204] Ilgin MA, Gupta SM. Physical programming: a review of the state of the art. Stud Inf Control 2012;21:349-66.

[205] Kongar E, Gupta SM. Disassembly-to-order system using Linear Physical Programming. In: 2002 IEEE International Symposium on Electronics and the Environment. 2002. p. 312-7.

[206] Jones DF, Mirrazavi SK, Tamiz M. Multi-objective meta-heuristics: an overview of the current state-of-the-art. Eur J Oper Res 2002;137:1-9.

[207] Goldberg DE. Genetic algorithms in search, optimization, and machine learning. Menlo Park: Addison-Wesley Reading; 1989.

[208] McGovern SM, Gupta SM. The disassembly line: balancing and modeling. New York: McGraw Hill; 2011.

[209] Gungor A, Gupta SM. Disassembly line in product recovery. Int J Prod Res 2002;40:2569-89.

[210] Battaia O, Dolgui A. A taxonomy of line balancing problems and their solution approaches. Int J Prod Econ 2013;142:259-77.

[211] Delorme X, Battaia O, Dolgui A. Multi-objective approaches for design of assembly lines. In: Benyoucef L, Hennet J-C, Tiwari MK, editors. Applications of multi-criteria and game theory approaches. New York: Springer; 2014. p. 31-56.

[212] Pegden CD, Shannon RE, Sadowski RP. Introduction to simulation using SIMAN. McGraw Hill; 1995

[213] Saaty TL. The analytic hierarchy process. New York: McGraw-Hill; 1980.

[214] Subramoniam R, Huisingh D, Chinnam RB. Aftermarket remanufacturing strategic planning decision-making framework: theory and practice. J Clean Prod 2010;18:1575-86.

[215] Ertugrul I, Karakasoglu N. Performance evaluation of Turkish cement firms with fuzzy analytic hierarchy process and TOPSIS methods. Expert Syst Appl 2009;36:702-15.

[216] Saaty TL. Decision making with dependence and feedback: the analytic network process. Pittsburgh, PA: RWS Publications; 1996.
[217] Cooper WW, Seiford LM, Zhu J, Cooper WW, Seiford LM. Data envelopment analysis: history, models, and interpretations. In: Handbook on data envelopment analysis. Springer US; 2011. p. 1-39.

[218] Wu W-W. Choosing knowledge management strategies by using a combined ANP and DEMATEL approach. Expert Syst Appl 2008;35:828-35.

[219] Govindan K, Khodaverdi R, Jafarian A. A fuzzy multi criteria approach for measuring sustainability performance of a supplier based on triple bottom line approach. J Clean Prod 2012;47:345-54.

[220] Bari F, Leung V. Application of ELECTRE to network selection in a hetereogeneous wireless network environment. In: IEEE Wireless Communications and Networking Conference. 2007. p. 3810-5.

[221] Teixeira de Almeida A. Multicriteria decision model for outsourcing contracts selection based on utility function and ELECTRE method. Comput Oper Res 2007;34:3569-74.

[222] Brans J-P, Mareschal B. Promethee methods. In: Multiple criteria decision analysis: state of the art surveys. New York: Springer; 2005. p. $163-86$.

[223] Mareschal B, De Smet Y. Visual PROMETHEE: developments of the PROMETHEE and GAIA multicriteria decision aid methods. In: IEEE International Conference on Industrial Engineering and Engineering Management. 2009. p. 1646-9.

[224] Min H. International supplier selection: a multi-attribute utility approach. Int J Phys Distrib Logist Manag 1994;24:24-33.

[225] Opricovic S, Tzeng G-H. Compromise solution by MCDM methods: a comparative analysis of VIKOR and TOPSIS. Eur J Oper Res 2004;156: 445-55.

[226] Ishizaka A, Nemery P. Multi-criteria decision analysis: methods and software. West Sussex: John Wiley \& Sons; 2013.

[227] Xu LD. Case based reasoning. IEEE Potentials 1994;13:10-3.

[228] Kolodner J. An introduction to case-based reasoning. Artif Intell Rev 1992;6:3-34.

[229] Kuo Y, Yang T, Huang G-W. The use of grey relational analysis in solving multiple attribute decision-making problems. Comput Ind Eng 2008;55:80-93. 